\title{
Reproductive cycle and biochemical composition of Hexaplex trunculus (Gastropoda: Muricidae) from Bizerte lagoon, northern Tunisia
}

\author{
Ines H. Gharsallah ${ }^{1, *}$, Paulo Vasconcelos ${ }^{2}$, Nedra Zamouri-Langar ${ }^{1}$, \\ Hechmi Missaoui $^{3}$ \\ ${ }^{1}$ Institut National des Sciences et Technologies de la Mer (INSTM), Port de Pêche, 2060 La Goulette, Tunisia \\ ${ }^{2}$ Instituto Nacional de Recursos Biológicos (INRB, I.P.) / IPIMAR, Avenida 5 de Outubro s/n, 8700-305 Olhão, Portugal \\ ${ }^{3}$ Direction Générale de la Pêche et de l'Aquaculture (DGPA), Ministère de l'Agriculture et des Ressources Hydrauliques, \\ 30, Rue Alain Savary, 1002 Tunis, Tunisia
}

\begin{abstract}
This study investigates the reproductive cycle, size at first sexual maturity and biochemical composition of Hexaplex trunculus from the Bizerte lagoon (northern Tunisia). Overall, females predominated over males, resulting in an unbalanced sex ratio of 1.2:1. Males dominated in the smaller size classes $(<40 \mathrm{~mm}$ shell length, SL), sex ratios were balanced at the 40 to $50 \mathrm{~mm}$ SL range, and females dominated in the larger size classes (>50 mm SL). The gonad developmental stages and the gonadosomatic index (GSI) indicated that $H$. trunculus apparently has an annual reproductive cycle with extended periods of gonadal activity. In both sexes, examination of the appearance of the gonads showed that gamete release occurred mainly from March to May (with an apparent spawning between March and April), followed by a period of empty gonads between June and August. Sexual maturity occurred at smaller sizes in males $\left(\mathrm{SL}_{50}=41.02 \mathrm{~mm} \mathrm{SL}\right)$ than in females $\left(\mathrm{SL}_{50}=\right.$ $50.47 \mathrm{~mm} \mathrm{SL}$ ). The contents of protein, lipids and carbohydrates were invariably greater in the gonads than in the foot, confirming the key role of the reproductive tissues in energetic storage. The monthly variation in protein, lipids and carbohydrates in the gonads followed the oscillation in the relative proportion of developed gonads and in the GSI, reflecting energetic mobilisation during maturation and spawning. Overall, the data gathered in this study constitutes valuable baseline information for making preliminary recommendations to the fishing community targeting $H$. trunculus in the Bizerte lagoon. Further studies and more solid data on the reproductive cycle of the species are required before definitive management measures for this locally important artisanal fishery can be proposed.
\end{abstract}

KEY WORDS: Reproductive cycle - Spawning season - Size at sexual maturity - Biochemical composition $\cdot$ Fisheries management $\cdot$ Hexaplex trunculus $\cdot$ Muricidae $\cdot$ Bizerte lagoon

\section{INTRODUCTION}

Gastropods represent $\sim 2 \%$ of the marine molluscs harvested worldwide (Leiva \& Castilla 2002). Muricidae is a large family comprising 8 subfamilies represented by $\sim 1300$ species that are distributed worldwide (Houart 2001). Despite this remarkable number of species, only a few muricids have commercial value, including 'el loco' Concholepas concholepas, 'caracol locate' Thais chocolata and 'caracol trumulco' Chorus giganteus in South America (Leiva \& Castilla 2002), the purple dye murex Bolinus brandaris (Martín et al. 1995) and the banded murex Hexaplex trunculus in Europe (Vasconcelos et al. 2008a).

The banded murex Hexaplex trunculus is a widespread Mediterranean species whose distribution in 
the Atlantic is mainly restricted to the coasts of Portugal and Morocco, and the Madeira and Canary archipelagos (Poppe \& Goto 1991, Houart 2001). This species is harvested for human consumption and has commercial value in several Mediterranean countries such as Spain, Italy, Croatia, Cyprus and Turkey (Fischer et al. 1987), as well as along the Atlantic coasts of Spain (mainly in Andalusia) (Anon 2001) and Portugal (mainly in Algarve) (Vasconcelos et al. 2008a). In the Bizerte lagoon (northern Tunisia), the banded murex is the target species of an artisanal fishery using baited traps, but is also a bycatch species in fishing nets (Gharsallah et al. 2004). The banded murex constitutes a locally important fishing resource in the Bizerte lagoon, with estimated monthly catches of $\sim 1.8$ tons between 1995 and 1999 (I. H. Gharsallah unpubl. data), but the fishery lacks specific regulations (e.g. minimum landing size, closed seasons in fishing activity).

While some studies on the reproductive biology and gametogenic cycle of the banded murex have been done recently in other geographical areas (Tirado et al. 2002, Vasconcelos et al. 2004, 2008b,c), analogous information for Hexaplex trunculus populations from Tunisia is available only from the studies of Lahbib et al. $(2004,2010)$. Additionally, the only data available on the biochemical composition of $H$. trunculus and its correlation to growth and reproduction was reported by Vasconcelos et al. (2009).

Information on the reproductive cycle is essential for the development of a suitable exploitation strategy for this locally important fishing resource. In this context, the aim of the present study is to describe the reproductive cycle of Hexaplex trunculus from the Bizerte lagoon through data on the sex ratio, size at sexual maturity, gonadosomatic index, and through macroscopic examination of gonads. These data are complemented by information on the seasonal variation in some key biochemical components (lipids, proteins and carbohydrates) of the foot and gonads. Ultimately, the practical objective of the present study was to provide baseline information and preliminary recommendations for an adequate exploitation of $H$. trunculus in the Bizerte lagoon. A rational exploitation strategy for this fishery is needed before overfishing causes harmful effects thus ensuring the long-term sustainable exploitation of the resource.

\section{MATERIALS AND METHODS}

Study site and sampling. The Bizerte lagoon is located on the northern coast of Tunisia $\left(37^{\circ} 8^{\prime}\right.$ to $37^{\circ} 14^{\prime} \mathrm{N}$, $9^{\circ} 46^{\prime}$ to $9^{\circ} 56^{\prime}$ E) (Fig. 1). Of elliptical shape, the lagoon has a total area of $\sim 128 \mathrm{~km}^{2}(\mathrm{~N}-\mathrm{S}=11 \mathrm{~km}, \mathrm{E}-\mathrm{W}=$
$13 \mathrm{~km}$ ) and an average depth of $7 \mathrm{~m}$ (Béjaoui et al. 2008). During the annual cycle, seawater temperature in the lagoon ranges from a minimum of $10^{\circ} \mathrm{C}$ in winter and a maximum of $28^{\circ} \mathrm{C}$ in summer (Harzallah 2002), whereas salinity ranges between 30 in winter and 38 in summer (Béjaoui et al. 2005).

In the Bizerte lagoon, Hexaplex trunculus is harvested using an artisanal lift net (more specifically a scoop net baited with byproducts from fish processing) that is locally called 'maltam' (Fig. 2). These scoop nets have a circular metallic structure of $30 \mathrm{~cm}$ diameter and a mesh size of $\sim 20$ to $30 \mathrm{~mm}$ (stretched net). Series of scoop nets (separated by $\sim 3 \mathrm{~m}$ ) are connected to each other through a main line, with a plastic buoy at the end of the gear. Each fisherman operates 50 to 300 scoop nets (depending on the market demand and frequency of sales). The gears are set on relatively shallow bottoms (3 to $4 \mathrm{~m}$ depth) and catches are retrieved daily.

The present study was scheduled in 2 sequential phases: the first (October 2004 to December 2005) aimed to describe the reproductive cycle of the species, and the second (May 2005 to April 2006) aimed to estimate the size at sexual maturity and assess the seasonal variation in the gonadosomatic index and primary biochemical composition throughout an annual cycle. Fishery landings of Hexaplex trunculus from the Bizerte lagoon were randomly sampled during the entire study period (October 2004 to April 2006). Each month, 100 snails were collected for laboratory analyses (except in July 2005, due to problems with the poor quality of their preservation). During the study period, observations were made in the field, and fishing surveys with local fishermen (that use baited traps and fishing nets) as well as interviews with local shellfish farmers were conducted to gather information on the seasonal variation in the abundance of egg masses/ collective spawns of $H$. trunculus in the lagoon.

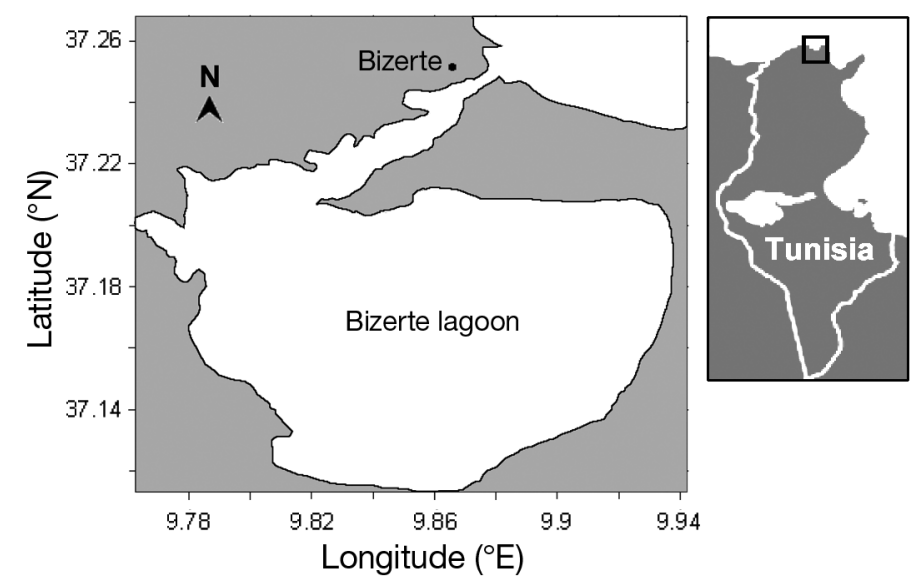

Fig. 1. Bizerte lagoon (northern Tunisia) 

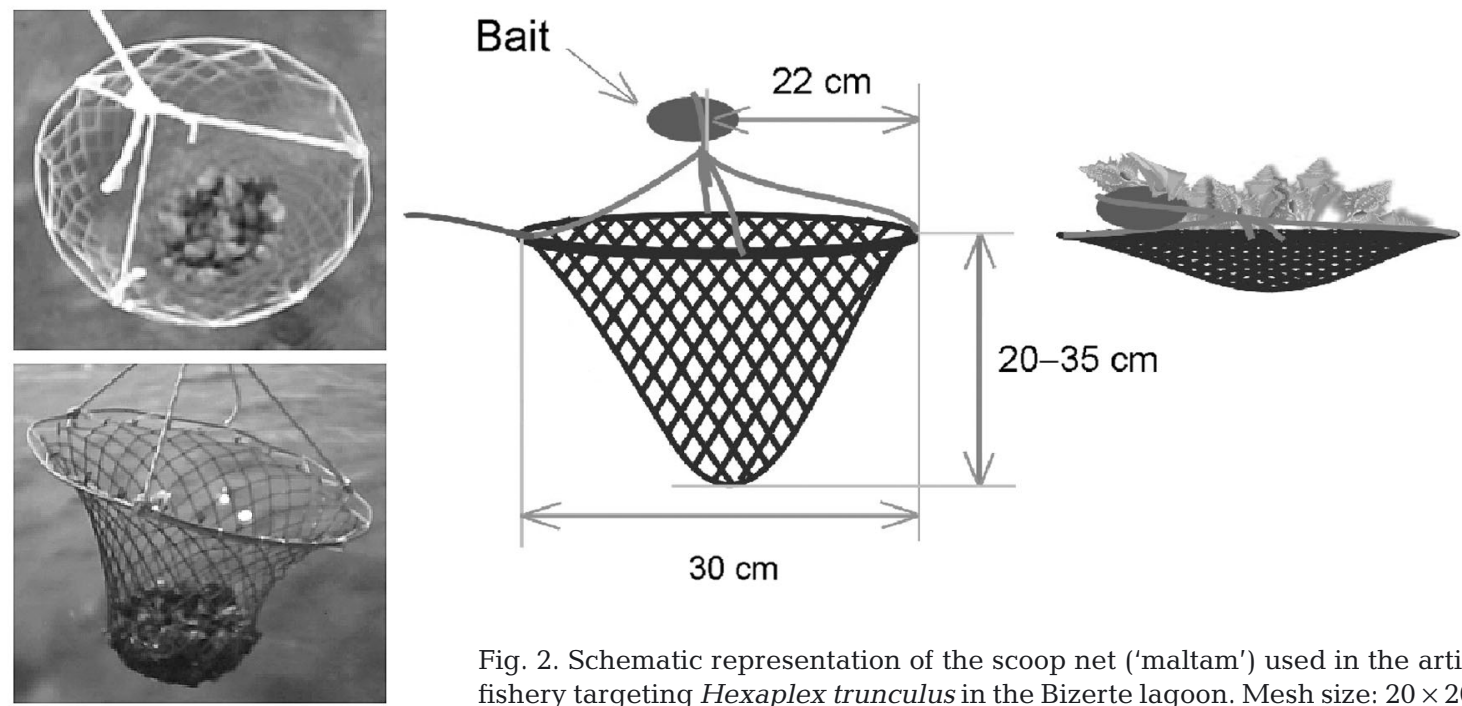

\section{$20-35 \mathrm{~cm}$}

Fig. 2. Schematic representation of the scoop net ('maltam') used in the artisanal fishery targeting Hexaplex trunculus in the Bizerte lagoon. Mesh size: $20 \times 20 \mathrm{~mm}$

In the laboratory, individuals were measured for shell length (SL) with a digital caliper (precision of $0.01 \mathrm{~mm}$ ) and weighed for total weight (TW) on a toploading digital balance (precision of $0.01 \mathrm{~g}$ ). After breaking the shells in a bench vice and removing the soft body, specimens were sexed: males were identified by the presence of a penis and lack of a capsule gland; females were identified by the presence of a bursa copulatrix and the associated capsule gland. The sex ratio (presented both as percentages of sexes and as F:M ratio) was determined monthly and according to size classes (5 $\mathrm{mm} \mathrm{SL).}$

Reproductive cycle. Approximately 70 ind. (SL $\geq$ $50 \mathrm{~mm}$ ) were examined monthly to assess the stages of gonad development through macroscopic observation of the gonads of both sexes, together with: the vesicula seminalis in males and the capsule gland in females. The degree of gonad development was determined by examining the appearance of the gonads using a scale with 3 stages: Stage 0 or empty, in which the gonads of both sexes are undistinguishable from the adjacent digestive gland, and males and females present inconspicuous vesicula seminalis and capsule glands, respectively; Stage 1 or intermediate, in which the gonads are very small but can be distinguished from the digestive gland; and Stage 2 or full, in which males have developed brown testes with a conspicuous whitish vesicula seminalis, whereas females show yellow ovaries and large white capsule glands.

Based on the macroscopic examination of gonads, the size at first sexual maturity was estimated by sampling individuals with a broad size range prior to the spawning period. After plotting the relative frequency of individuals with full gonads (Stage 2) as a function of shell length (grouped into $5 \mathrm{~mm}$ SL classes), the size at sexual maturity was estimated by fitting a logistic regression to the data using the following equation:

$$
\% \text { Maturity }=1 /\left[1+\mathrm{e}^{-\mathrm{r}\left(\mathrm{SL}-\mathrm{SL}_{50}\right)}\right]
$$

where \%Maturity is the proportion of mature individuals in the sample, $\mathrm{r}$ is the regression slope and $\mathrm{SL}_{50}$ is the size at first sexual maturity (defined as the shell length at which $50 \%$ of the population is mature).

The gonadosomatic index (GSI) of both sexes was calculated to assess the seasonality of the reproductive cycle. In Hexaplex trunculus (as in other Muricidae), the gonad is located on the dorsal side in close contact with the underlying digestive gland. For this reason, gonads were carefully dissected under a binocular microscope to avoid loss of gonadal tissue or inclusion of other tissues, and thus minimise measurement errors. The gonads were weighed (GW) on a digital balance (precision of $0.001 \mathrm{~g}$ ) and the GSI was calculated using the following equation (Martel et al. 1986a, Power \& Keegan 2001):

GSI $(\%)=($ gonad weight $/$ eviscerated weight $) \times 100$

In the present study, the GSI was calculated monthly for 30 standard-sized ind. (SL > $50 \mathrm{~mm}$ ). The GSI for standard-sized specimens was calculated to highlight the seasonal variation in weight that is actually associated with the reproductive cycle, by minimising the interference of increasing somatic weight during growth (Martel et al. 1986a, Cledón et al. 2005, Vasconcelos et al. 2008c).

Biochemical composition. The biochemical composition of Hexaplex trunculus was analysed to detect 
seasonal changes in the contents of moisture, protein, total lipids and carbohydrates as maturation progressed. Each month, 24 specimens (divided into 4 replicates, each with 6 ind.) with shell lengths that were greater than the size at sexual maturity $(50 \mathrm{~mm}$ SL) were analysed. In order to distinguish between reproductive and non-reproductive tissues, and thus compare their biochemical composition and storage function for reproductive purposes, the soft parts were separated into 2 types of samples: foot and gonad (dissected from the adjacent digestive gland).

The moisture content of the foot and gonads was quantified by drying to constant weight in an oven at $100^{\circ} \mathrm{C}$. The protein content was analysed according to the dye-binding method of Bradford (1976), using bovine serum albumin (Sigma) as a standard. Total lipids were extracted with chloroform:methanol (2:1 v/v) using the method of Bligh \& Dyer (1959). After centrifugation at $5000 \mathrm{rpm}$, the chloroformic lower phase containing the lipids was recovered, the solvent was removed by aerating the sample with nitrogen to dryness, and the dry mass of total lipids was then measured gravimetrically. The glucose oxidase method was used to quantify carbohydrates (Biomaghreb kit). Results are expressed as percentages of the biochemical component on wet weight basis (g $100 \mathrm{~g}_{\text {wet }} \mathrm{wt}^{-1}$ ).

Statistical analysis. The chi-square test was used to compare the population sex ratio with parity (1:1). ANOVA was employed to compare the biochemical composition between tissues and between months. The assumptions of normality of the data and homogeneity of variances were tested and whenever ANOVA assumptions were not met, the non-parametric Kruskal-Wallis test was performed. Where significant differences among groups were detected during the ANOVA or Kruskal-Wallis tests, pairwise multiple comparisons were made using Tukey's or Dunn's tests (Zar 1996). Statistical analyses were performed using the software package SigmaStat (version 3.5) using p $<0.05$ as the significance level.

\section{RESULTS}

\section{Sex ratio}

A total of 1478 Hexaplex trunculus were examined during the study period. Females $(n=829)$ dominated over males ( $\mathrm{n}=649$ ), resulting in an unbalanced sex ratio of 1.2:1 $\left(\chi^{2}=21.92, p<0.05\right)$. The sex ratio showed marked inter-month variability, with predominance of females in 7 of the 15 mo of the study (October to December 2004, June, August, October and November 2005). In contrast, males predominated during a single month (February 2005) (Fig. 3a).
The variation in the sex ratio in different size classes revealed an evident dominance of males among smaller specimens and the prevalence of females in larger size classes (Fig. 3b). In fact, a significant increasing trend in the proportion of females was detected with increasing specimen size $(\mathrm{r}=0.925, \mathrm{p}<$ 0.01 ), with females dominating in sizes $>50 \mathrm{~mm} \mathrm{SL}$, sex ratios being balanced between 40 and $50 \mathrm{~mm} \mathrm{SL}$, and males dominating in sizes $<40 \mathrm{~mm}$ SL.

\section{Reproductive cycle}

Based on external observations of the gonads, the banded murex showed an apparently annual reproductive cycle (Fig. 4). Both sexes presented variable proportions of all gonad stages throughout the year, but their relative importance varied during the reproductive cycle. This simultaneous occurrence of different developmental stages complicates the exact definition of the periods of maturation, gamete release and recovery of the gonads. Gametogenesis was roughly continuous in both sexes, with males and females with full gonads being present during the entire study period. Moreover, males presented invariably higher frequencies of full gonads (Stage 2) than females, reflecting a greater reproductive effort throughout the year.

The highest frequencies of ripe males (with full gonads) were recorded from October 2004 to March 2005 and from October to December 2005. Gamete release (or transfer from the testis to the seminal vesicle) in males occurred mainly between March and May, with the sharp decrease in the percentage of males with full gonads clearly signalling a peak in sperm emission or transfer between March and April. Afterwards, a relatively short resting phase was detected between June and August, followed by a period of gonad recovery between September and December (Fig. 4a).

The highest frequencies of ripe females (with full gonads) were detected between October 2004 and March 2005, and again from October to December 2005. The maturation period was followed by a significant decrease in the percentage of females with full gonads between March and April, indicating a spawning peak (which was synchronous with the peak of male gametic emission). The following period that is characterised by lower proportions of full gonads denoted the occurrence of a resting phase mainly between June and August. A reasonably continuous phase of gonad recovery occurred after summer, which was more evident between September and December. Finally, the monthly fluctuation in the frequency of ripe females suggested the occurrence of additional, minor and sporadic spawning events (e.g. between October and November in both years sampled) (Fig. 4b). 

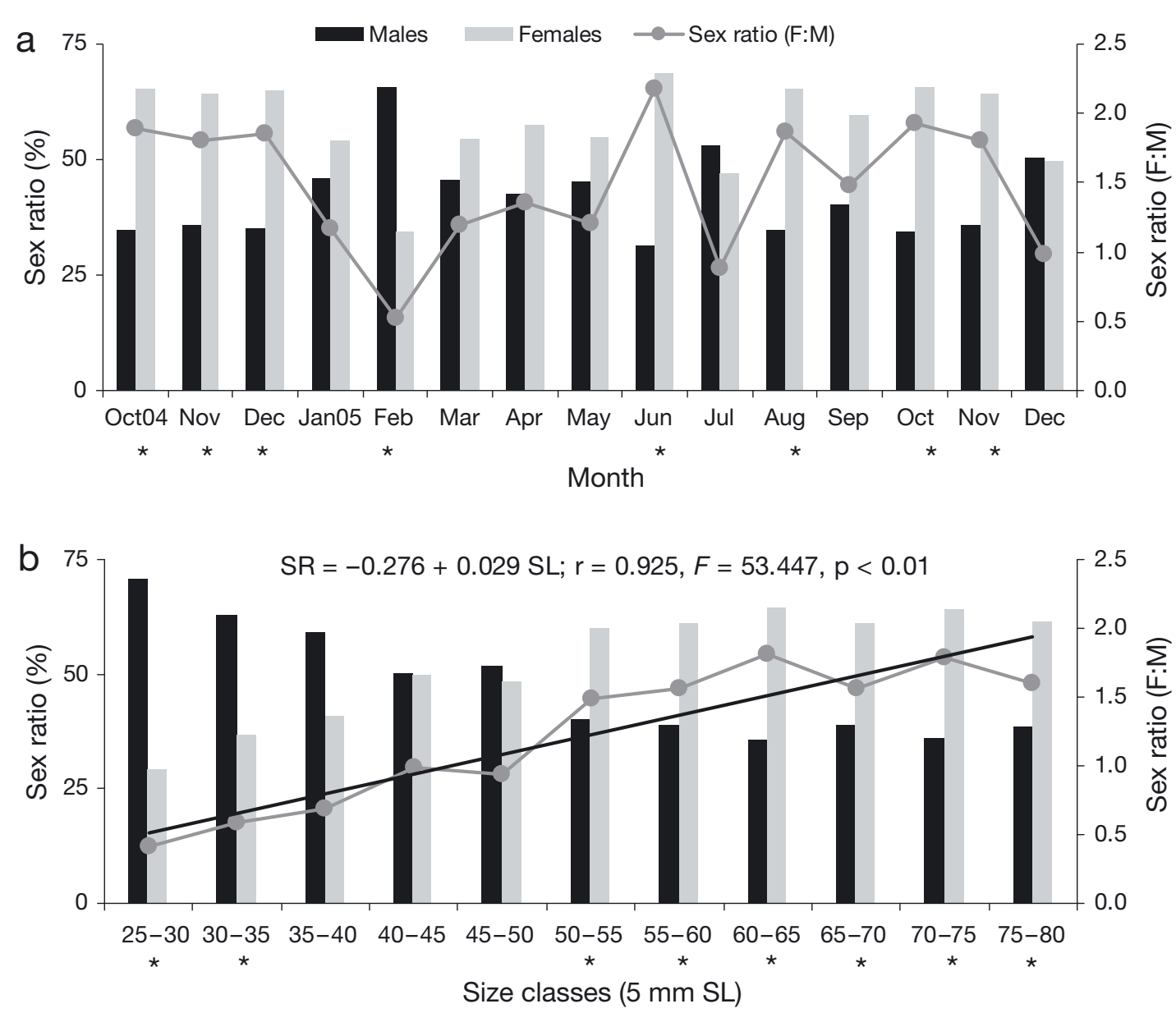

Fig. 3. Hexaplex trunculus. Sex ratios (percentage of sexes and F:M ratio): (a) variation in monthly samples during the first study period (October 2004 to December 2005); (b) variation according to specimen size (grouped into 5 mm shell length [SL] classes). Asterisks denote monthly samples and size classes with significantly unbalanced sex ratios $\left(\chi^{2}\right.$-test, $\left.\mathrm{p}<0.05\right)$

\section{Gonadosomatic index}

The GSI displayed statistically significant fluctuations throughout the year (ANOVA: Tukey's test, $\mathrm{p}<0.05$ ). In addition, the GSI showed a similar trend and synchrony between sexes during the reproductive cycle (Fig. 5). In both sexes, an abrupt decrease in the GSI was detected between March and April, corroborating the occurrence of a spawning peak in this period. Diverse anecdotal sources, such as information from field observations, fishing surveys with local fishermen and interviews with local shellfish farmers, confirmed the abundance of egg masses/collective spawns of Hexaplex trunculus in the Bizerte lagoon during the main spawning season established in this study (see Discussion).

The lowest GSI values were recorded between June and August, also supporting the existence of a resting phase during summer. Thereafter, the GSI in both sexes increased from September until November (males) or December (females), corresponding to the period of gonad recovery. A small decrease in female GSI was observed between December and January, signalling a sporadic and secondary spawning episode (which, due to its irregular character, is likely subject to slight yearly variations). Finally, this phase was followed by a continuous increase in the GSI until March, i.e. prior to the beginning of the spawning season (Fig. 5).

\section{Size at sexual maturity}

The estimation of the size at sexual maturity (Fig. 6) was based on the macroscopic examination of gonads of 163 males and 144 females sampled in February and March 2006. This sampling period was selected to coincide with the maturation peak recognized in the previous year (i.e. immediately before the predictable spawning season). The smallest male with full gonads was $34.42 \mathrm{~mm}$ SL and size at sexual maturity was estimated at $41.03 \mathrm{~mm} \mathrm{SL}$. In males, $>70 \%$ of the individuals with SL $>40 \mathrm{~mm}, 90 \%$ of the individuals with SL > $55 \mathrm{~mm}$, and all individuals with SL > $70 \mathrm{~mm}$ were sex- 

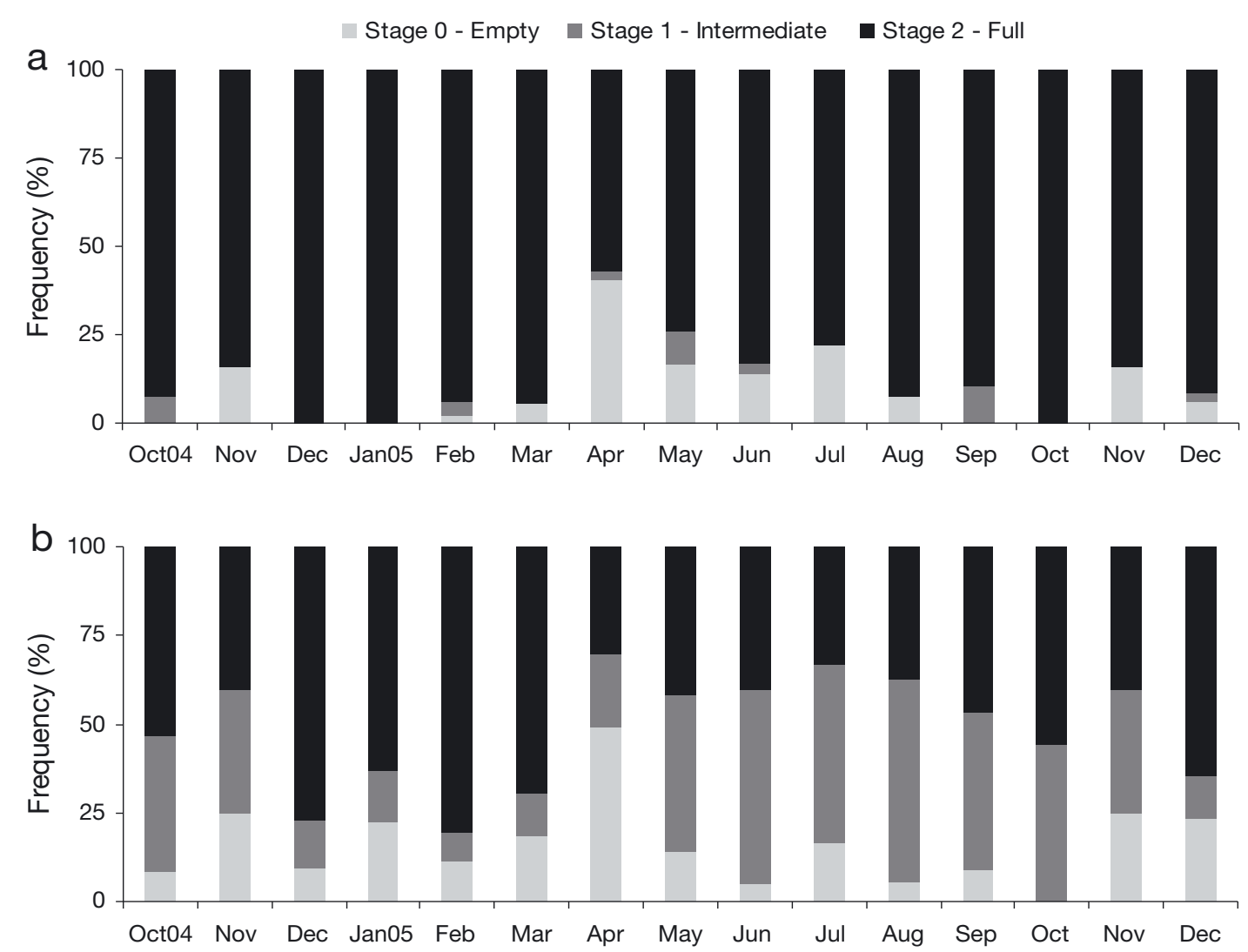

Fig. 4. Hexaplex trunculus. Percentage occurrence of the macroscopic stages of gonad development during the first study period (October 2004 to December 2005): (a) males, (b) females

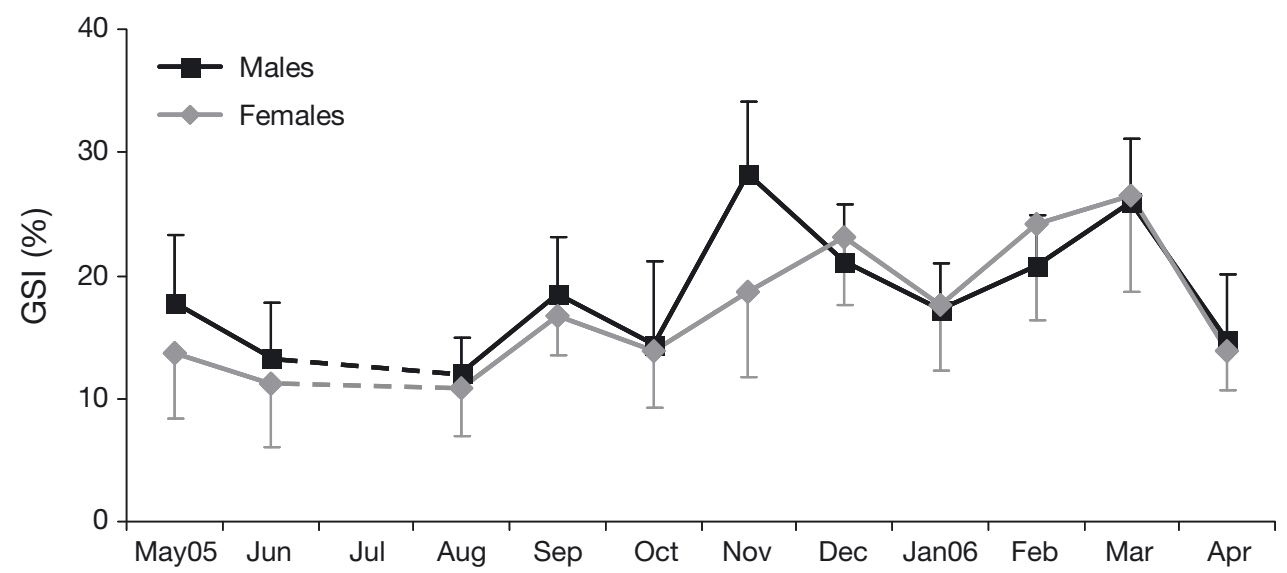

Fig. 5. Hexaplex trunculus. Seasonal variation in the gonadosomatic index (GSI) of both sexes during the second study period (May 2005 to April 2006). Error bars: mean \pm SD

ually mature (Fig 6a). The smallest female with full gonads was $36.07 \mathrm{~mm}$ SL and size at sexual maturity was estimated at $50.47 \mathrm{~mm} \mathrm{SL}$. In females, $>65 \%$ of the individuals with SL $>50 \mathrm{~mm}, 90 \%$ of the individuals with SL > $55 \mathrm{~mm}$, and all individuals with $\mathrm{SL}>65 \mathrm{~mm}$ were sexually mature (Fig. 6b).

\section{Biochemical composition}

Among the biochemical components analysed in the foot and the gonads of Hexaplex trunculus, the protein, lipid and carbohydrate contents showed marked variations throughout the reproductive cycle, whereas the 

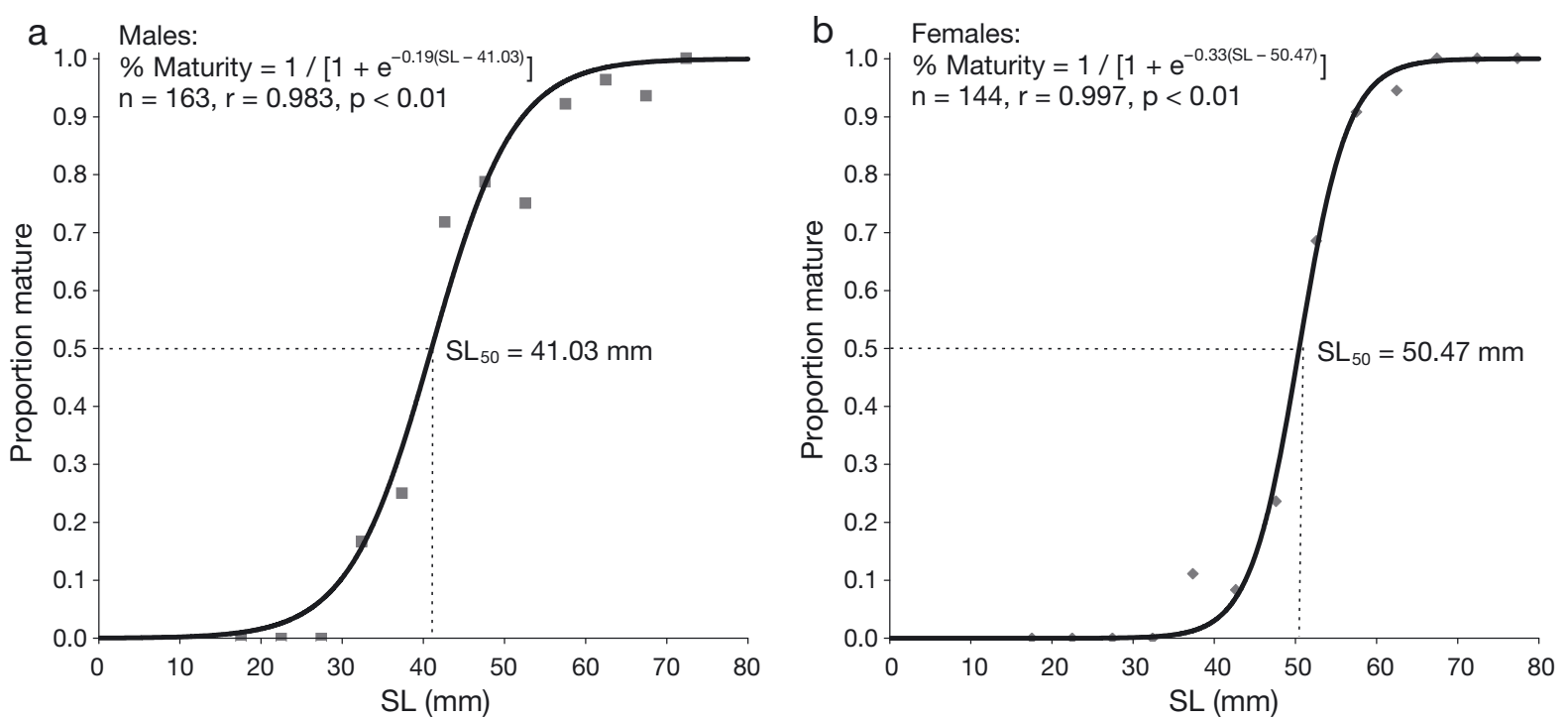

Fig. 6. Hexaplex trunculus. Sizes at first sexual maturity, showing the proportion of mature individuals (with full gonads, based on the macroscopic classification of gonad development) in relation to shell length (grouped into 5 mm SL classes): (a) males, (b) females

moisture content did not show significant oscillations (Fig. 7).

The protein content was significantly different between the 2 types of organs examined (ANOVA: $\left.F_{1,66}=434.01, \mathrm{p}<0.05\right)$, accounting for $15.86 \pm 0.59 \%$ of wet wt in the foot and $28.00 \pm 1.91 \%$ of wet wt in the gonads (Fig. 7b). The foot showed monthly differences in the protein content (ANOVA: $F_{10,33}=6.74, \mathrm{p}<0.05$ ), with a sharp decrease between February (19.76 \pm $1.76 \%$ of wet wt) and March $(12.10 \pm 1.46 \%$ of wet wt). Significant monthly differences were also detected in the protein content of the gonads (ANOVA: $F_{10,33}=$ $4.66, \mathrm{p}<0.05)$, with a marked increase between May $(19.87 \pm 1.45 \%$ of wet wt) and November $(32.77 \pm$ $1.79 \%$ of wet wt), and a gradual decrease thereafter (Fig. 7b).

The lipid content was also significantly different between the 2 types of organs (ANOVA: $F_{1,66}=535.49$, $\mathrm{p}<0.05)$, varying from $1.14 \pm 0.29 \%$ of wet wt in the foot and $3.49 \pm 1.07 \%$ of wet wt in the gonads (Fig. $7 \mathrm{c}$ ). In the foot, lipid content did not display significant monthly variation (ANOVA: $F_{10,33}=1.788, p>0.05$ ). In contrast, lipid content in the gonads increased steadily from $1.81 \pm 0.16 \%$ of wet wt in May to $4.32 \pm 0.46 \%$ of wet wt in November. After a slight decrease in December, lipids increased until February (reaching the peak value of $4.44 \pm 0.76 \%$ of wet wt) and decreased sharply once again between March and April (ANOVA: $F_{10,33}=$ 9.65, p < 0.05) (Fig. 7c).

Following a similar trend, carbohydrate contents were also significantly different between the foot and the gonads (ANOVA: $F_{1,66}=711.70, \mathrm{p}<0.05$ ), being $1.47 \pm 0.15 \%$ and $3.28 \pm 0.52 \%$ of wet wt, respectively
(Fig. 7d). The carbohydrate content of the foot showed significant monthly differences during the study period (Kruskal-Wallis: $H_{10,44}=24.57, \mathrm{p}<0.05$ ). The carbohydrate content of the gonads, however, presented high inter-month variability (ANOVA: $F_{10,33}=15.86, \mathrm{p}<$ $0.05)$, with a maximum value in February (4.31 \pm $0.14 \%$ of wet wt) followed by a significant decrease during March and April, reaching the minimum value in May $(2.59 \pm 0.40 \%$ of wet wt). Except for a slight decrease between September and October, the carbohydrate contents of the gonads remained quite stable between June $(3.66 \pm 0.39 \%$ of wet wt) and January $(3.34 \pm 0.12 \%$ of wet wt) (Fig. $7 \mathrm{~d})$.

\section{DISCUSSION}

Overall, the samples of banded murex showed a sex ratio of $1.2 \mathrm{~F}: 1 \mathrm{M}$, which is significantly different from parity (1:1). This predominance of females is common in gonochoristic gastropods (Fretter \& Graham 1994) and agrees with previous findings in Hexaplex trunculus from the Bizerte lagoon (Lahbib et al. 2004) and in another muricid (B. brandaris) from Spain (Ramón \& Amor 2002). In contrast, $H$. trunculus populations from Spain (Tirado et al. 2002) and from Portugal (Vasconcelos et al. 2008b) showed balanced sex ratios (1:1). In the present study the monthly sex ratios varied throughout the year, with a significantly higher proportion of males in spring, coinciding with the identified spawning season of $H$. trunculus in the Bizerte lagoon. This may be related to the initiation of copulation and/or migration of mature females for spawning, 

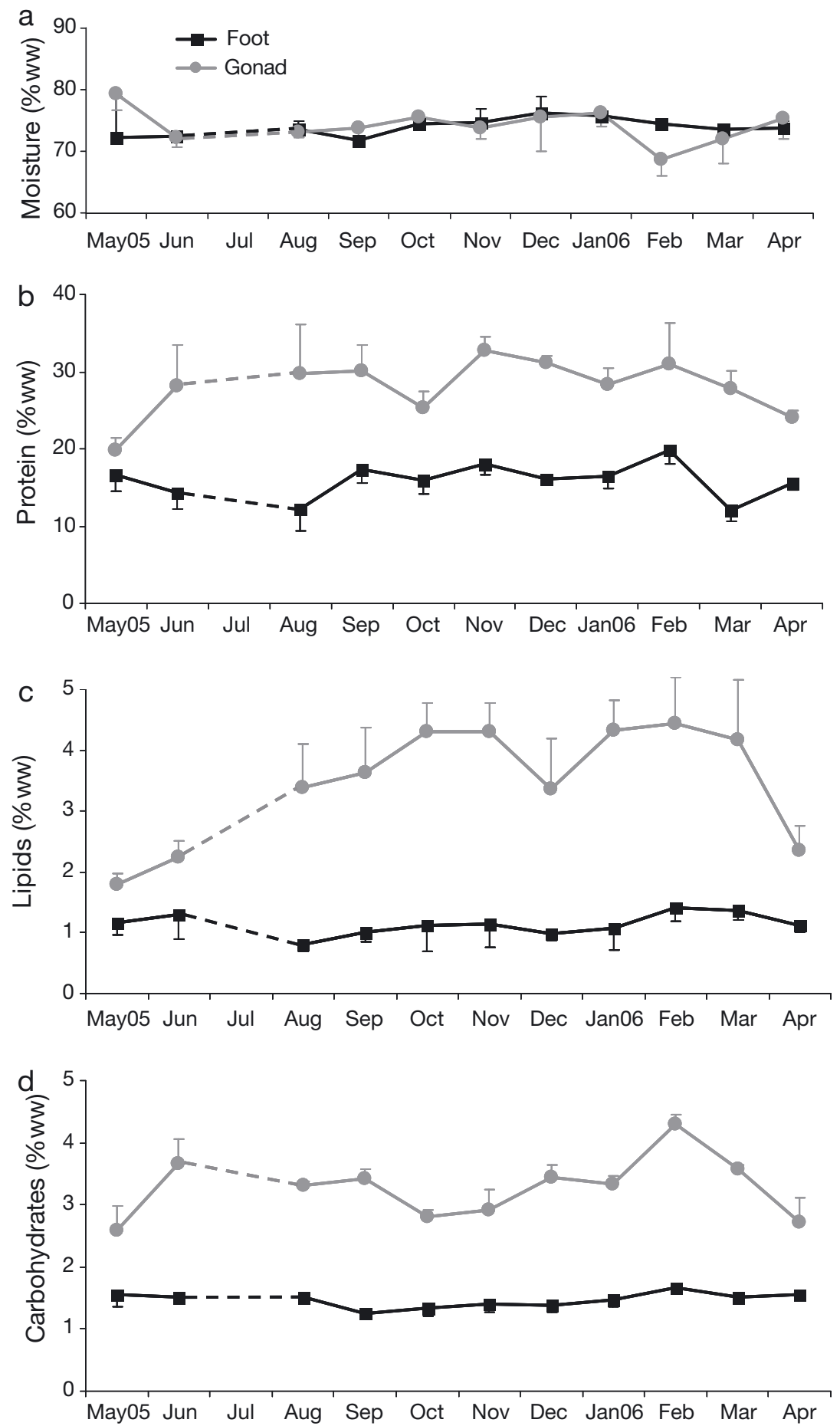

Fig. 7. Hexaplex trunculus. Seasonal variation in the biochemical composition of the foot and the gonads during the second study period (May 2005 to April 2006): (a) moisture, (b) protein, (c) lipids, (d) carbohydrates. Data are presented as percentages of the biochemical component on wet weight (ww) basis ( $100 \mathrm{~g}$ wet $\mathrm{wt}^{-1}$ ). Error bars: mean $\pm \mathrm{SD}$

with a consequent decrease in the feeding activity (Martel et al. 1986a,b, Himmelman \& Hamel 1993, Kideys et al. 1993, Power \& Keegan 2001). Indeed, the behavioural response to baits differs depending on sex and developmental stage in whelks, which are less likely to move towards baited traps during periods of increased reproductive activity (McQuinn et al. 1988, Power \& Keegan 2001, Ilano et al. 2003). Finally, the banded murex displayed female-biased sex ratios in larger size classes, corroborating findings reported for 
H. trunculus from Portugal (Vasconcelos et al. 2008b). This predominance of females among larger and older individuals might be due to differential growth between sexes (particularly after reaching sexual maturity), with females allocating more energy towards growth than for reproduction. In addition, in gastropod populations that are highly affected by imposex, which is the case for $H$. trunculus from the Bizerte lagoon (Lahbib et al. 2008a,b, 2009), reduced female reproductive effort generally leads to increased somatic growth (Axiak et al. 1995, Rilov et al. 2000).

The gametogenic cycle of Hexaplex trunculus apparently comprises an extended period of gonadal activity. During the study period, both sexes displayed variable proportions of different gonad stages throughout the year, but males presented invariably higher frequencies of full gonads compared to females. The long period of maturation in both sexes and the high proportion of ripe males throughout the year might be a reproductive strategy to increase the number of copulas (Ramón \& Amor 2002). Moreover, female H. trunculus can store viable sperm in the sperm-ingesting gland (receptaculum seminis) for long periods before fecundation. These characteristics might increase the reproductive success and explain the occurrence of minor and sporadic spawning episodes in this species. Extensive periods of gametic activity in $H$. trunculus have been previously reported in the Bizerte lagoon (Lahbib et al. 2004) and in other countries in the Mediterranean Sea and Atlantic Ocean, such as Italy (Albanese et al. 1983), Spain (Tirado et al. 2002) and Portugal (Vasconcelos et al. 2008b).

The GSI showed good agreement with the macroscopic classification of gonad stages, revealing a coincident trend between sexes and marked synchrony in the gonadal development of males and females. Vasconcelos et al. (2008c) also observed roughly synchronous gonad maturation between sexes for Hexaplex trunculus from Portugal based on GSI calculated using gonad area instead of gonad weight. Gamete release in both male and female $H$. trunculus occurred mainly from March to May, with a spawning peak between March and April. The information from field observations, fishing surveys with local fishermen and interviews with local shellfish farmers altogether provided valuable indications concerning the occurrence and abundance of egg masses/collective spawns throughout the year in the Bizerte lagoon. These sources of anecdotal information corroborated results on the main spawning season of $H$. trunculus as established in this study through macroscopic observation of the gonads and the GSI: the first and little spawns are found in small numbers in March; large egg masses (clusters of egg capsules) resulting from collective/ communal oviposition are found in April and May; empty spawns (egg capsules with opened escape aperture, i.e. after the hatching of the post-metamorphic embryos) begin to appear in June. Similarly, and although yearly variations are possible, $H$. trunculus populations throughout the distributional range of the species present a spawning peak in late spring to early summer (generally between April and July) (Barash \& Zenziper 1980, Tirado et al. 2002, Lahbib et al. 2004, Vasconcelos et al. 2004, 2008b,c).

The long and nearly continuous gonadal activity of Hexaplex trunculus implied a short resting phase. Indeed, after gametic emission in both sexes, a period with higher frequencies of empty and intermediate stages of gonad development (June to August) was detected, although specimens with full gonads were invariably present in all monthly samples. Similarly, short resting phases in the $H$. trunculus reproductive cycle have also been detected in populations both from the Mediterranean Sea (Italy and Spain) (Albanese et al. 1983, Tirado et al. 2002) and the Atlantic Ocean (Portugal) (Vasconcelos et al. 2008b).

Sexual maturity was observed to occur at 41.02 and $50.47 \mathrm{~mm}$ SL in males and females, respectively. These values are close to the $\mathrm{SL}_{50}$ estimated for this species in Spain (50 mm SL) (Tirado et al. 2002). Differences in the size at first sexual maturity of males and females might be due to differential growth between the sexes (Power \& Keegan 2001) or to a delay in sexual maturation of females (Cledón et al. 2008). Sexual maturation at smaller sizes in males than in females has also been reported for other gastropod species, including Adelomelon brasiliana (Cledón et al. 2008), Buccinum cyaneum (Miloslavich \& Dufresne 1994), Buccinum isaotakii (Ilano et al. 2003), Odontocymbiola magellanica (Bigatti et al. 2008) and Zidona dufresnei (Giménez \& Penchaszadeh 2003).

Environmental factors influence the quantity and quality of available food and regulate metabolic activities, and therefore play a decisive role in the storage cycle (Gabbott 1983, Carrasco et al. 2006). In addition, the species' reproductive cycle and particularly the processes associated with gonad maturation also determine the events of accumulation and depletion of stored energetic reserves (Ansell 1972). The biochemical composition analyses of Hexaplex trunculus from the Bizerte lagoon revealed that the contents of proteins, lipids and carbohydrates were invariably higher in the gonads than in the foot. Moreover, despite showing a relatively similar trend, their variation throughout the year was more evident in the gonads than in the foot. These seasonal fluctuations certainly result from the interaction of various factors (e.g. seawater temperature and food availability), but also depend on species growth and reproduction. Confirming the key role of the reproductive tissues in energetic storage, 
the oscillations in the contents of proteins, lipids and carbohydrates were correlated with seasonal variations in the GSI, and consequently with the processes of gonad maturation and spawning. A similar interpretation has been made for $H$. trunculus (Vasconcelos et al. 2009) and for other gastropod species, such as Buccinum undatum (Brokordt et al. 2003), Haliotis varia (Najmudeen 2007), Patella depressa (Morais et al. 2003), Stramonita haemastoma (Belisle \& Stickle 1978), Turbo brunneus (Ramesh \& Ravichandran 2008) and Turbo sarmaticus (McLachlan \& Lombard 1980).

In a review of lipids in marine invertebrates, Giese (1966) concluded that lipids are usually the most important reserve material. In conformity with this, lipids are apparently the main energetic source for the reproductive effort of Hexaplex trunculus, increasing gradually during gonad development, displaying highest levels in full gonads, and declining sharply during gamete release and spawning (coincident with the decrease in the frequency of full gonads and in the GSI). Similar trends in the lipid content throughout the reproductive cycle, revealing a 'lipid-oriented' metabolism, have also been reported for other molluscan species, such as Eurhomalea exalbida (Lomovasky et al. 2004), Haliotis rubra (Litaay \& De Silva 2003), Morula granulata (Uma Devi et al. 1985) and Turbo sarmaticus (McLachlan \& Lombard 1980). Furthermore, the high protein content in the gonads of $H$. trunculus may constitute an alternative energetic reserve during gametogenesis, as reported in some bivalve species (Beninger \& Lucas 1984, Galap et al. 1997). For instance, gonadal protein could be accumulated as vitellin associated with lipids as in Crassostrea gigas (Li et al. 2000), and might be used to synthesize lipids or carbohydrates as in T. sarmaticus (McLachlan \& Lombard 1980). Interestingly, the monthly variation in the foot protein content of $H$. trunculus showed an evident decrease immediately before the spawning peak (March to April), which might suggest a possible mobilisation of protein reserves to support the reproductive effort. However, the irregular trend in the foot protein content of Haliotis varia was attributed to its involvement in growth and metabolism rather than in reproduction (Najmudeen 2007).

The information gathered in the present study concerning the estimation of the size at first sexual maturity is essential for establishing a minimum landing size (MLS) for the catches of Hexaplex trunculus in the Bizerte lagoon. Following the estimation of $\mathrm{SL}_{50}$ (41.02 and $50.47 \mathrm{~mm}$ SL in males and females, respectively) and taking into account the absence of external sexual dimorphism in this species (Vasconcelos et al. 2006), the MLS of $H$. trunculus must be $>50 \mathrm{~mm}$ SL. Indeed, as a precautionary measure and in order to ensure the reproduction of the species and promote the long-term sustainable exploitation of the resource, a MLS of $55 \mathrm{~mm}$ SL (size at which $90 \%$ of males and females are sexually mature) should be legally stipulated. Just for comparison purposes, in the exportation of banded murex from Tunisia to some European countries, a MLS of $50 \mathrm{~mm}$ SL would meet the Portuguese regulations (Vasconcelos et al. 2008a), whereas a MLS of $60 \mathrm{~mm} \mathrm{SL}$ would fulfill the Spanish regulations (Anon. 2001). An information campaign should be conducted to elucidate the importance of respecting the MLS and the main disadvantages, both to fishermen (lower fishing yield and profit) and consumers (lower meat yield and nutritional value), of harvesting and consuming $H$. trunculus smaller than the MLS.

Considering the current scarcity of information on the species' biology, the present work makes a useful contribution to the current knowledge on the reproduction of Hexaplex trunculus in the Bizerte lagoon. Moreover, the results on the reproductive cycle and timing of the spawning season provide valuable baseline information for making preliminary recommendations to the fishing community targeting $H$. trunculus in the lagoon. In particular, fishermen should be convinced of the importance of reducing the fishing effort during the spawning peak of the species in the lagoon (March to April), in order to protect the spawning stock and the collective spawns, and consequently ensure an adequate recruitment. In the near future, this recommendation should ideally be replaced by the effective implementation of a closed season in the fishing activity coincident with the spawning peak of $H$. trunculus. However, the proposal and implementation of such definitive fishery management measures require more solid information on the reproductive cycle of the species, particularly the confirmation of the timing of the main spawning event of $H$. trunculus in the Bizerte lagoon. Thus, further studies are needed to complement the data gathered in the present work, including additional sampling and histological analyses of the gonads to comprehensively describe the gametogenic cycle. In summary, this information may help promote the long-term sustainable exploitation of this locally important fishing resource in the Bizerte lagoon.

Acknowledgements. This study was partly undertaken as part of a joint research project entitled 'Comparative study of the fisheries of gastropod molluscs with commercial value (banded murex - Hexaplex trunculus and purple dye murex Bolinus brandaris) in the Portuguese and Tunisian coasts', funded by the Fundação para a Ciência e Tecnologia (FCT, Portugal) and the Ministère de la Recherche Scientifique, Technologie et Développement des Compétences (Tunisia). I.H.G. was supported by a research grant from INSTM (Tunisia) and P.V. was supported by a post-doctoral grant from FCT (SFRH/BPD/26348/2006). We also thank R. Cattaneo-Vietti and 2 anonymous referees for valuable comments and suggestions that greatly improved the manuscript. 


\section{LITERATURE CITED}

Albanese MP, Calabrò C, Acosta Pomar MLC (1983) Ciclo biológico di Trunculariopsis trunculus L. (Moll. Gast. Pros.) vivente nel Lago di Faro. Mem Biol Mar Oceanogr 13:133-147

Anon (2001) Especies de interés pesquero en el litoral de Andalucía. II. Invertebrados. Junta de Andalucía, Consejería de Agricultura y Pesca, Sevilla

Ansell AD (1972) Distribution, growth and seasonal changes in biochemical composition for the bivalve Donax vitatus (da Costa) from Kames Bay, Millport. J Exp Mar Biol Ecol 10:137-150

> Axiak V, Vella AJ, Micallef D, Chircop P, Mintoff B (1995) Imposex in Hexaplex trunculus (Gastropoda; Muricidae): first results from biomonitoring of tributyltin contamination in the Mediterranean. Mar Biol 121:685-691

Barash A, Zenziper Z (1980) Egg masses of Mollusca from Mediterranean waters of Israel and notes on reproduction of the fresh water species Theodoxus jordani and Melanoides tuberculata. Veliger 22:299-317

Béjaoui B, Ben Charrada R, Moussa M, Ben Hamadou R, Harzallah A, Chapelle A (2005) Caractérisation hivernale de la lagune de Bizerte. Bull Inst Nat Sci Technol Mer Salammbô 32:79-91

Béjaoui B, Harzallah A, Moussa M, Chapelle A, Solidoro C (2008) Analysis of hydrobiological pattern in the Bizerte lagoon (Tunisia). Estuar Coast Shelf Sci 80:121-129

Belisle W, Stickle WB (1978) Seasonal patterns in the biochemical constituents and body component indexes of the muricid gastropod, Thais haemastoma. Biol Bull 155: 259-272

Beninger PG, Lucas A (1984) Seasonal variations in condition index, reproductive activity, and gross biochemical composition of two species of adult clam reared in a common habitat: Tapes decussatus L. (Jeffreys) and Tapes philippinarum (Adams and Reeve). J Exp Mar Biol Ecol 79: 19-37

Bigatti G, Marzinelli EM, Penchaszadeh PE (2008) Seasonal reproduction and sexual maturity in Odontocymbiola magellanica (Neogastropoda, Volutidae). Invertebr Biol 127: 314-326

Bligh EG, Dyer WJ (1959) A rapid method of total lipid extraction and purification. Can J Biochem Physiol 37:911-917

Bradford MM (1976) A rapid and sensitive method for the quantitation of microgram quantities of protein utilizing the principle of protein-dye binding. Anal Biochem 72: 248-254

Brokordt KB, Guderley HE, Guay M, Gaymer CF, Himmelman JH (2003) Sex differences in reproductive investment: maternal care reduces escape capacity in the whelk Buccinum undatum. J Mar Biol Assoc UK 291:161-180

Carrasco CA, Navarro JM, Leiva GE (2006) Biochemical composition and tissue weight of Chorus giganteus (Gastropoda: Muricidae) exposed to different diets and temperatures during reproductive conditioning. Interciencia 31:376-381

Cledón M, Arntz W, Penchaszadeh PE (2005) Gonadal cycle in an Adelomelon brasiliana (Neogastropoda: Volutidae) population off Buenos Aires province, Argentina. Mar Biol 147:439-445

> Cledón M, Arntz W, Penchaszadeh PE (2008) Size and age at sexual maturity in Adelomelon brasiliana (Neogastropoda: Volutidae) off Argentina. J Mar Biol Assoc UK 88: 169-173

Fischer W, Schneider M, Bauchot ML (1987) Fiches FAO d'identification des espèces pour les besoins de la pêche.
Méditerranée et Mer Noire. I. Végétaux et invertébrés. FAO, Rome

Fretter V, Graham A (1994). British prosobranch molluscs: their functional anatomy and ecology. The Ray Society, London

Gabbott PA (1983) Developmental and seasonal metabolic activities in marine molluscs. In: Hochachka PW (ed) The Mollusca. Vol 2. Environmental biochemistry and physiology. Academic Press, New York, p 165-217

Galap C, Leboulenger F, Grillot JP (1997) Seasonal variations in biochemical constituents during the reproductive cycle of female dog cockle Glycymeris glycmeris. Mar Biol 129: 625-634

Gharsallah IH, Zamouri-Langar N, Missaoui H, El Abed A (2004) Étude de la croissance relative et de la biomasse d'Hexaplex trunculus dans la lagune de Bizerte. Bull Soc Zool Fr 129:427-436

Giese AC (1966) Lipids in the economy of marine invertebrates. Physiol Rev 46:244-298

- Giménez J, Penchaszadeh PE (2003) Size at first sexual maturity in Zidona dufresnei (Caenogastropoda: Volutidae) of the south-western Atlantic Ocean (Mar del Plata, Argentina). J Mar Biol Assoc UK 83:293-296

Harzallah A (2002) Etat actuel et évolution de l'exploitation halieutique et aquacole des lagunes - cas de la lagune de Bizerte. Rapp Inst Nat Sci Technol Mer Salammbô, p 128

Himmelman JH, Hamel JR (1993) Diet, behaviour and reproduction of the whelk Buccinum undatum in the northern Gulf of St. Lawrence, eastern Canada. Mar Biol 116: $423-430$

Houart R (2001) A review of the recent Mediterranean and Northeastern Atlantic species of Muricidae. Ed. Evolver, Rome

Ilano AS, Fujinaga K, Nakao S (2003) Reproductive cycle and size at sexual maturity of the commercial whelk Buccinum isaotakii in Funka Bay, Hokkaido, Japan. J Mar Biol Assoc UK 83:1287-1294

Kideys A, Nash RDM, Hartnoll RG (1993) Reproductive cycle and energetic cost of reproduction of the neogastropod Buccinum undatum in the Irish Sea. J Mar Biol Assoc UK 73:391-403

Lahbib Y, Trigui El-Menif N, Le Pennec M, Boumaïza M (2004) Données sur le cycle reproducteur du mollusque gastéropode Hexaplex trunculus (Linné, 1758) de la Lagune de Bizerte (Tunisie). Bull Soc Zool Fr 129:407-418

> Lahbib Y, Boumaïza M, Trigui El Menif N (2008a) Imposex expression in Hexaplex trunculus from the North Tunis Lake transplanted to Bizerta channel (Tunisia). Ecol Indic 8:239-245

Lahbib Y, Abidli S, Trigui El Menif N (2008b) Imposex level and penis malformation in Hexaplex trunculus from the Tunisian coast. Am Malacol Bull 24:79-89

> Lahbib Y, Abidli S, Chiffoleau JF, Averty B, Trigui El Menif N (2009) First record of butyltin body burden and imposex status in Hexaplex trunculus (L.) along the Tunisian coast. J Environ Monit 11:1253-1258

Lahbib Y, Abidli S, Trigui El-Menif N (2010) Laboratory study of the intracapsular development and juvenile growth in the banded murex Hexaplex trunculus (Gastropoda: Muricidae). J World Aquacult Soc 41:18-34

Leiva GE, Castilla JC (2001) A review of the world marine gastropod fishery: evolution of catches, management and the Chilean experience. Rev Fish Biol Fish 11:283-300

Li Q, Osada M, Mori K (2000) Seasonal biochemical variations in Pacific oyster gonadal tissue during sexual maturation. Fish Sci 66:502-508

Litaay M, De Silva SS (2003) Spawning season, fecundity and proximate composition of the gonads of wild-caught 
blacklip abalone (Haliotis rubra) from Port Fairy waters, south eastern Australia. Aquat Living Resour 16:353-361 Lomovasky BJ, Gabriela M, Calvo J (2004) Seasonal changes in biochemical composition of the clam, Eurhomalea exalbida (Bivalvia: Veneridae), from the Beagle channel, Argentina. J Shellfish Res 23:81-87

Martel A, Larrivée DH, Klein KR, Himmelman JH (1986a) Reproductive cycle and seasonal feeding activity of the neogastropod Buccinum undatum. Mar Biol 92:211-221

Martel A, Larrivée DH, Himmelman JH (1986b) Behaviour and timing of copulation and egg-laying in the neogastropod Buccinum undatum L. J Exp Mar Biol Ecol 96:27-42

Martín P, Sánchez P, Ramón M (1995) Population structure and exploitation of Bolinus brandaris (Mollusca: Gastropoda) off the Catalan coast (northwestern Mediterranean). Fish Res 23:319-331

McLachlan A, Lombard HW (1980) Seasonal variations in energy and biochemical components of an edible gastropod, Turbo sarmaticus (Turbinidae). Aquaculture 19:117-125

McQuinn IH, Gendron L, Himmelman JH (1988) Area of attraction and effective area fished by a whelk (Buccinum undatum) trap under variable conditions. Can J Fish Aquat Sci 45:2054-2060

Miloslavich P, Dufresne L (1994) Development and effect of female size on egg and juvenile production in the neogastropod Buccinum cyaneum from the Saguenay Fjord. Can J Fish Aquat Sci 51:2866-2871

Morais S, Boaventura D, Narciso L, Ré P, Hawkins SJ (2003) Gonad development and fatty acid composition of Patella depressa Pennant (Gastropoda: Prosobranchia) populations with different patterns of spatial distribution, in exposed and sheltered sites. J Exp Mar Biol Ecol 294:61-80

Najmudeen TM (2007) Variation in biochemical composition during gonad maturation of the tropical abalone Haliotis varia Linnaeus1758 (Vetigastropoda: Haliotidae). Mar Biol Res 3:454-461

Poppe GT, Goto Y (1991) European seashells, Vol 1 (Polyplacophora, Caudofoveata, Solenogastra, Gastropoda). Verlag Christa Hemmen, Wiesbaden

Power AJ, Keegan BF (2001) Seasonal patterns in the reproductive activity of the red whelk Neptunea antiqua (Mollusca: Prosobranchia) in the Irish Sea. J Mar Biol Assoc UK 81:243-250

Ramesh R, Ravichandran S (2008) Seasonal variation on the proximate composition of Turbo brunneus. Int J Zool Res $4: 28-34$

Editorial responsibility: Riccardo Cattaneo-Vietti, Genova, Italy
Ramón M, Amor MJ (2002) Reproductive cycle of Bolinus brandaris and penis genital duct size variations in a population affected by imposex. J Mar Biol Assoc UK 82: 435-442

- Rilov G, Gasith A, Evans SM, Benayahu Y (2000) Unregulated use of TBT-based antifouling paints in Israel (Eastern Mediterranean): high contamination and imposex levels in two species of marine gastropods. Mar Ecol Prog Ser 192:229-238

Tirado C, Rodríguez de la Rúa A, Bruzón MA, López JI, Salas C, Márquez I (2002) La reproducción de bivalvos y gasterópodos de interés pesquero en Andalucía. Junta de Andalucía, Consejería de Agricultura y Pesca, Huelva

Uma Devi V, Prabhakara Rao Y, Prasada Rao DGV (1985) Seasonal changes in the biochemical composition of a tropical intertidal prosobranch Morula granulata (Duclos). J Molluscan Stud 51:248-256

Vasconcelos P, Gaspar MB, Joaquim S, Matias D, Castro M (2004) Spawning of Hexaplex (Trunculariopsis) trunculus (Gastropoda: Muricidae) in the laboratory: description of spawning behaviour, egg masses, embryonic development, hatchling and juvenile growth rates. Invertebr Reprod Dev 46:125-138

Vasconcelos P, Gaspar MB, Castro M (2006) Development of indices for nonsacrificial sexing of imposex-affected Hexaplex (Trunculariopsis) trunculus (Gastropoda: Muricidae). J Molluscan Stud 72:285-294

Vasconcelos P, Carvalho S, Castro M, Gaspar MB (2008a) The artisanal fishery for muricid gastropods (banded murex and purple dye murex) in the Ria Formosa lagoon (Algarve coast, southern Portugal). Sci Mar 72:287-298

- Vasconcelos P, Lopes B, Castro M, Gaspar MB (2008b) Gametogenic cycle of Hexaplex (Trunculariopsis) trunculus (Gastropoda: Muricidae) in the Ria Formosa lagoon (Algarve coast, southern Portugal). J Mar Biol Assoc UK 88: 321-329

Vasconcelos P, Lopes B, Castro M, Gaspar MB (2008c) Comparison of indices for the assessment of reproductive activity in Hexaplex trunculus (Gastropoda: Muricidae). Mar Biol Res 4:392-399

> Vasconcelos P, Gaspar MB, Castro M, Nunes ML (2009) Influence of growth and reproductive cycle on the meat yield and proximate composition of Hexaplex trunculus (Gastropoda: Muricidae). J Mar Biol Assoc UK 89:1223-1231

Zar JH (1996) Biostatistical analysis, 3rd edn. Prentice-Hall International, NJ

Submitted: February 3, 2010; Accepted: July 13, 2010

Proofs received from author(s): August 10, 2010 